\title{
Article
}

\section{Gene Expression Profiles in Two Razor Clam Populations: Discerning Drivers of Population Status}

\author{
Heather A. Coletti ${ }^{1, *}$, Lizabeth Bowen ${ }^{2}$, Brenda E. Ballachey ${ }^{3}$, Tammy L. Wilson ${ }^{4}$, Shannon Waters ${ }^{2}$, \\ Michael Booz ${ }^{5}$, Katrina L. Counihan ${ }^{6,7} \mathbb{C}^{\text {, Tuula E. Hollmen }}{ }^{6,8}$ and Benjamin Pister ${ }^{9}$ \\ 1 Southwest Alaska Network, Inventory \& Monitoring Program, National Park Service, \\ Fairbanks, AK 99709, USA \\ 2 Western Ecological Research Center, U.S. Geological Survey, Davis, CA 95616, USA; lbowen@usgs.gov (L.B.); \\ swaters@usgs.gov (S.W.) \\ 3 Alaska Science Center, U.S. Geological Survey, Anchorage, AK 99501, USA; beballachey@gmail.com \\ 4 Massachusetts Cooperative Fish and Wildlife Research Unit, University of Massachusetts, \\ U.S. Geological Survey, Amherst, MA 01002, USA; tammywilson@umass.edu \\ 5 Alaska Department of Fish and Game, Homer, AK 99603, USA; michael.booz@alaska.gov \\ 6 Alaska SeaLife Center, Seward, AK 99664, USA; katrinac@alaskasealife.org (K.L.C.); \\ tuulah@alaskasealife.org (T.E.H.) \\ 7 Eastern Regional Research Center, U.S. Department of Agriculture, Wyndmoor, PA 19038, USA \\ 8 College of Fisheries and Ocean Sciences, University of Alaska Fairbanks, Seward, AK 99664, USA \\ 9 Kenai Fjords National Park, National Park Service, Seward, AK 99664, USA; Benjamin_Pister@nps.gov \\ * Correspondence: Heather_Coletti@nps.gov; Tel.: +1-907-382-0373
}

Citation: Coletti, H.A.; Bowen, L.; Ballachey, B.E.; Wilson, T.L.; Waters,

S.; Booz, M.; Counihan, K.L.;

Hollmen, T.E.; Pister, B. Gene

Expression Profiles in Two Razor

Clam Populations: Discerning Drivers of Population Status. Life 2021, 11, 1288. https://doi.org/ $10.3390 /$ life11121288

Academic Editors: Seth E Frietze, Michael Sheriff and Abbey Wilson

Received: 2 September 2021

Accepted: 18 November 2021

Published: 24 November 2021

Publisher's Note: MDPI stays neutral with regard to jurisdictional claims in published maps and institutional affiliations.

Copyright: (c) 2021 by the authors. Licensee MDPI, Basel, Switzerland. This article is an open access article distributed under the terms and conditions of the Creative Commons Attribution (CC BY) license (https:// creativecommons.org/licenses/by/ $4.0 /)$.

\begin{abstract}
With rapidly changing marine ecosystems, shifts in abundance and distribution are being documented for a variety of intertidal species. We examined two adjacent populations of Pacific razor clams (Siliqua patula) in lower Cook Inlet, Alaska. One population (east) supported a sport and personal use fishery, but this has been closed since 2015 due to declines in abundance, and the second population (west) continues to support commercial and sport fisheries. We used gene expression to investigate potential causes of the east side decline, comparing razor clam physiological responses between east and west Cook Inlet. The target gene profile used was developed for razor clam populations in Alaska based on physiological responses to environmental stressors. In this study, we identified no differences of gene expression between east and west populations, leading to two potential conclusions: (1) differences in factors capable of influencing physiology exist between the east and west and are sufficient to influence razor clam populations but are not detected by the genes in our panel, or (2) physiological processes do not account for the differences in abundance, and other factors such as predation or changes in habitat may be impacting the east Cook Inlet population.
\end{abstract}

Keywords: Pacific razor clam; Siliqua patula; gene expression; environmental drivers; clam population decline; predation

\section{Introduction}

Alaska's Pacific razor clams (Siliqua patula) are important for commercial and personal harvest and as prey for marine animals [1-3]. Currently, the only commercial razor clam fishery in Alaska occurs in west Cook Inlet (WCI) near Polly Creek, and the annual harvest has averaged approximately 900,000 clams since 1980 [3,4]. Recreational clam harvests occur more widely in Cook Inlet and provide a boost to local economies [5]. The state's largest sport and personal use Pacific razor clam fishery historically occurred along a 50-mile area of beach between the Kasilof and Anchor rivers on the east side of Cook Inlet (ECI), where an average of almost one million clams per year were harvested from 1977-2006 [6], similar to the annual commercial harvest that is ongoing on WCI. Razor clam harvest was not evenly distributed throughout the ECI area and primarily occurred on the Clam Gulch and Ninilchik area beaches. This fishery remained stable during this period 
with consistent recruitment of new age classes (juveniles) to the beaches, and harvest was comprised of a broad range of age classes on all beaches [6]. However, between 2009 and 2012 , the annual number of clams harvested per digger declined by $41 \%$ concurrent with a decline in harvest effort below the long-term mean (1977-2008), indicating a dramatic decline in the ECI razor clam population [3,7]. During this period of decline, average annual age and length compositions of the harvest were truncated to younger/smaller clams compared to historical averages and were comprised of fewer cohorts on all beaches regardless of harvest rates [8]. The human exploitation rate of razor clams throughout most of ECI was assumed to be low based on digger distribution and monitoring at more heavily harvested beaches at Clam Gulch and Ninilchik [9]. The clam decline resulted in restrictions of ECI clamming in 2013 with full closure in 2015; however, ECI razor clams have not recovered to historical abundances $[10,11]$. The causes of the decline through 2015 were unknown but were attributed to poor recruitment into the adult age classes and above average adult natural mortality [12]. In contrast, the razor clam fisheries in WCI have continued to support a commercial and personal use fishery over the same time frame [3].

East Cook Inlet beaches are accessible by road, and personal harvest pressures on razor clams there have been greater than in WCI, which is accessible only by boat or plane. Based on monitoring data, clam abundance among locations in ECI is not uniform [3], suggesting that razor clam populations are structured at small spatial scales. For example, recent surveys determined that at Ninilchik, juvenile clam mortality was $70 \%$, while at Clam Gulch it was only 10\% [3]. Razor clam recruitment is also variable among locations and across years with, for example, more consistent recruitment at Clam Gulch and less frequent, larger recruitments at the Ninilchik beaches [3]. Razor clam growth rates also differ among ECI locations, with increasing growth rates from north to south $[6,13]$. WCI razor clam data are primarily limited to commercial fishery data, which include digger effort (digger days), number harvested, and pounds harvested annually. The commercial harvest makes up over $97 \%$ of the total razor clam harvest annually in WCI, indicating the personal use and sport fishery is minimal [3].

Although causes for the decline of razor clams in ECI are unknown, there are potential differences beyond any effects of harvest in drivers between ECI and WCI. Geomorphological conditions vary between ECI and WCI and may contribute to differences in the quantity and stability of habitats [14]. However, ShoreZone ${ }^{\circledR}$, a mapping and classification system that specializes in the collection and interpretation of imagery of the coastal environment, indicates almost no difference in sediment type, wave exposure, or oil residence index across all sites [15]. Oceanographic processes in Cook Inlet contribute to seasonal and spatial variation in salinity and temperature [16] as well as plankton blooms [17]. Higher temperatures, salinity levels, and the presence of contaminants have been shown to suppress bivalve immune function, making them more susceptible to disease and parasites, potentially resulting in more severe infections [18,19]. More recent studies have highlighted food web complexity differences between ECI and WCI, likely due to the influence of glacial melt in the west, an influence which is absent in the east [20]. Additionally, top-level predators, including brown bears (Ursus arctos) [21] and sea otters (Enhydra lutris) [22] may be a factor, and if so, predation pressures will vary between ECI and WCI likely due to predator population density differences across the study region [23,24].

Increasingly, gene expression is being used as a tool to monitor nearshore marine ecosystems [25-27]. As an emerging field, gene expression focuses on mussels as sentinels of ocean health $[28,29]$, but methods are now widely applied across marine species, including invertebrates, mammals, birds, and fish [30-33]. These gene-based health diagnostics provide an opportunity for an alternate, holistic assessment of health, not only in individuals or populations, but potentially that of ecosystems [34]. Specifically, gene expression is the process by which information from the DNA template of a particular gene is transcribed into messenger RNA (mRNA) and eventually translated into a functional protein. The amount of a particular gene that is expressed is physiologically dictated by the number of 
intrinsic and extrinsic factors, including stimuli such as nutrient levels, toxin exposure, or changes in water chemistry or temperature. Expression analysis can effectively provide an early warning system for pathophysiological changes within an organism exposed to biological or physical stressors, as altered levels of gene expression will be evident prior to clinical manifestation $[26,35,36]$. The comparison of gene expression patterns identifies genes that are differentially expressed in distinct populations or in response to different treatments or exposures. For these reasons, we employed gene expression to improve our understanding of drivers that may influence razor clam populations in Cook Inlet.

In a previous study [37], we used gill tissue to identify a target gene expression profile for Pacific razor clams, based on known physiological responses to environmental stressors in other invertebrates (Table 1). For example, increased ocean acidification leads to increased levels of calmodulin (CaM) expression and would result in changes in metabolism and immune response [38,39]. Pathogen exposure likely leads to changes in levels of ferritin (Ferr) [40,41] and Peptidylprolyl isomerase A (PPIA) expression and would result in an inflammatory response [42]. Increased expression levels of both heat shock protein 70 (HSP70) and 90 (HSP90) provide cellular protection and are indicative of thermal and general stress (including pathogen exposure), while HSP90 expression levels are also indicators of contaminant exposure [43-46]. Sampling sites in Bowen et al. [37] were located within two national parks and considered to be pristine. However, our panel was able to identify significant differences in gene expression between parks and among sites within each park, which indicated variation in both large-scale and local environmental conditions.

Table 1. Genes selected to assess Pacific razor clam and ecosystem health.

\begin{tabular}{cc}
\hline Gene & Function \\
\hline Calmodulin (CaM) & Shell formation-indication of ocean acidification; \\
& metabolism, immune response ([38]—Barnacle Balanus \\
amphitrite; [39]—Grooved carpet shell clam, Ruditapes \\
decussatus; [47]—Eastern oyster, Crassostrea virginica)
\end{tabular}


Our objectives in this study were to: (1) determine gene expression profiles for Pacific razor clams from two areas, ECI and WCI, (2) assess differences in expression between the two areas, as well as among sites within each area, and (3) based on any differences (or lack thereof) that may be observed, provide insight as to possible drivers of the ECI razor clam decline. We hypothesized that the comparison of gene expression profiles between ECI and WCI would help differentiate between drivers affecting Pacific razor clams in ECI. If expression profiles differed among areas (or sites within an area), individual genes may suggest processes that have adversely affected razor clams in ECI. Although gene expression studies generally focus on genes that are differentially transcribed among groups, genes that show no difference among groups are also informative. If no expression differences are found, our conclusions can be interpreted in two ways: (1) differing environmental conditions exist but did not influence the molecular physiology reflected by the genes in our panel, or (2) other pressures such as predation or changes in a habitat may be impacting razor clam populations differentially but do not induce a physiological response. Our goal is to provide information to managers to better understand mechanisms limiting recovery of declining Pacific razor clam fisheries in Cook Inlet, Alaska.

\section{Materials and Methods}

\subsection{Study Organisms}

Razor clams were collected in July 2015 and 2016 at nine sites on the east coast of Cook Inlet (ECI; sites north to south: Cohoe, Clam Gulch North, Clam Gulch South, North Oil Pad Access, South Oil Pad Access, Ninilchik North, Ninilchik South, Ninilchik Bar, and Deep Creek) and at three sites along the west coast of Cook Inlet adjacent to Lake Clark National Park and Preserve (WCI; sites north to south: Polly Creek, Silver Salmon Creek, and Chinitna Bay [37]) (Figure 1). Ten clams were collected from each site in 2015 and again in 2016 (total of 120 each year). The ECI sites are monitored annually by the Alaska Department of Fish and Game (ADF\&G) while the sites in WCI were selected based on where clam presence had been confirmed by recreational human harvest [37]. Clams were collected at low tide, and sampling was constrained to the same low tide series for both east and west.

\subsection{Tissue Collection and RNA Extraction}

Gill tissue was collected from each clam and placed immediately into RNAlater (Ambion/Life Technologies, Grand Island, NY, USA). All tissue samples were stored at $-80{ }^{\circ} \mathrm{C}$. Total RNA was extracted from homogenized gill tissue using the RNeasy Lipid Tissue Mini Kit (Qiagen; Germantown, MD, USA). To remove contaminating genomic (g)DNA, the spin columns were treated with $10 \mathrm{U} \mu \mathrm{L}^{-1}$ of RNase-free DNase I (DNase, Amersham Pharmacia Biotech Inc.; PA, USA) at $20^{\circ} \mathrm{C}$ for $15 \mathrm{~min}$. RNA was then stored at $-80^{\circ} \mathrm{C}$ pending further analyses.

\section{3. cDNA Synthesis}

A standard cDNA synthesis was performed on $2 \mu \mathrm{g}$ of RNA template from each clam. Reaction conditions included 4 units reverse transcriptase (Omniscript, Qiagen, Valencia, CA, USA), $1 \mu \mathrm{M}$ random hexamers, $0.5 \mathrm{mM}$ each $\mathrm{dNTP}$, and 10 units RNase inhibitor, in RT buffer (Qiagen, Valencia, CA, USA). Reactions were incubated for $60 \mathrm{~min}$ at $37^{\circ} \mathrm{C}$, followed by an enzyme inactivation step of $5 \mathrm{~min}$ at $93^{\circ} \mathrm{C}$, and then stored at $-20^{\circ} \mathrm{C}$ until further analysis.

\subsection{Primer Design}

Primers used were developed by Bowen et al. [37]. Briefly, degenerate primer pairs developed for the razor clam were used on cDNA from three randomly selected clam samples. Degenerate primer pairs were designed to amplify five genes of interest and two reference genes. The PCR amplifications using these primers were performed on $20 \mathrm{ng}$ of each cDNA sample in $50 \mu \mathrm{L}$ volumes containing 20-60 pmol of each primer, $40 \mathrm{mM}$ 
Tris- $\mathrm{KOH}$ (pH 8.3), $15 \mathrm{mM} \mathrm{KOAc,} 3.5 \mathrm{mM} \mathrm{Mg}(\mathrm{OAc})_{2}, 3.75 \mu \mathrm{g} / \mathrm{mL}$ bovine serum albumin (BSA), $0.005 \%$ Tween-20, 0.005\% Nonidet-P40, $200 \mu \mathrm{M}$ each dNTP, and 5U of Advantage $2{ }^{\circledR}$ Taq polymerase (Clontech, Palo Alto, CA, USA). The PCR was performed on an MJ Research PTC-200 thermal cycler (MJ Research, Watertown, MA, USA) and consisted of 1 cycle at $94{ }^{\circ} \mathrm{C}$ for $3 \mathrm{~min}$, and then 40 cycles at $94{ }^{\circ} \mathrm{C}$ for $30 \mathrm{~s}$, at $60^{\circ} \mathrm{C}$ for $30 \mathrm{~s}$, and $72{ }^{\circ} \mathrm{C}$ for $2 \mathrm{~min}$, with a final extension step of $72{ }^{\circ} \mathrm{C}$ for $10 \mathrm{~min}$. The products of these reactions were electrophoresed on $1.5 \%$ agarose gels and resulting bands visualized by ethidium bromide staining. Definitive bands representing PCR products of a predicted base pair size of the targeted gene were excised from the gel and extracted and purified using a commercially available nucleic acid-binding resin (Qiaex II Gel extraction kit, Qiagen, Valencia, CA, USA).

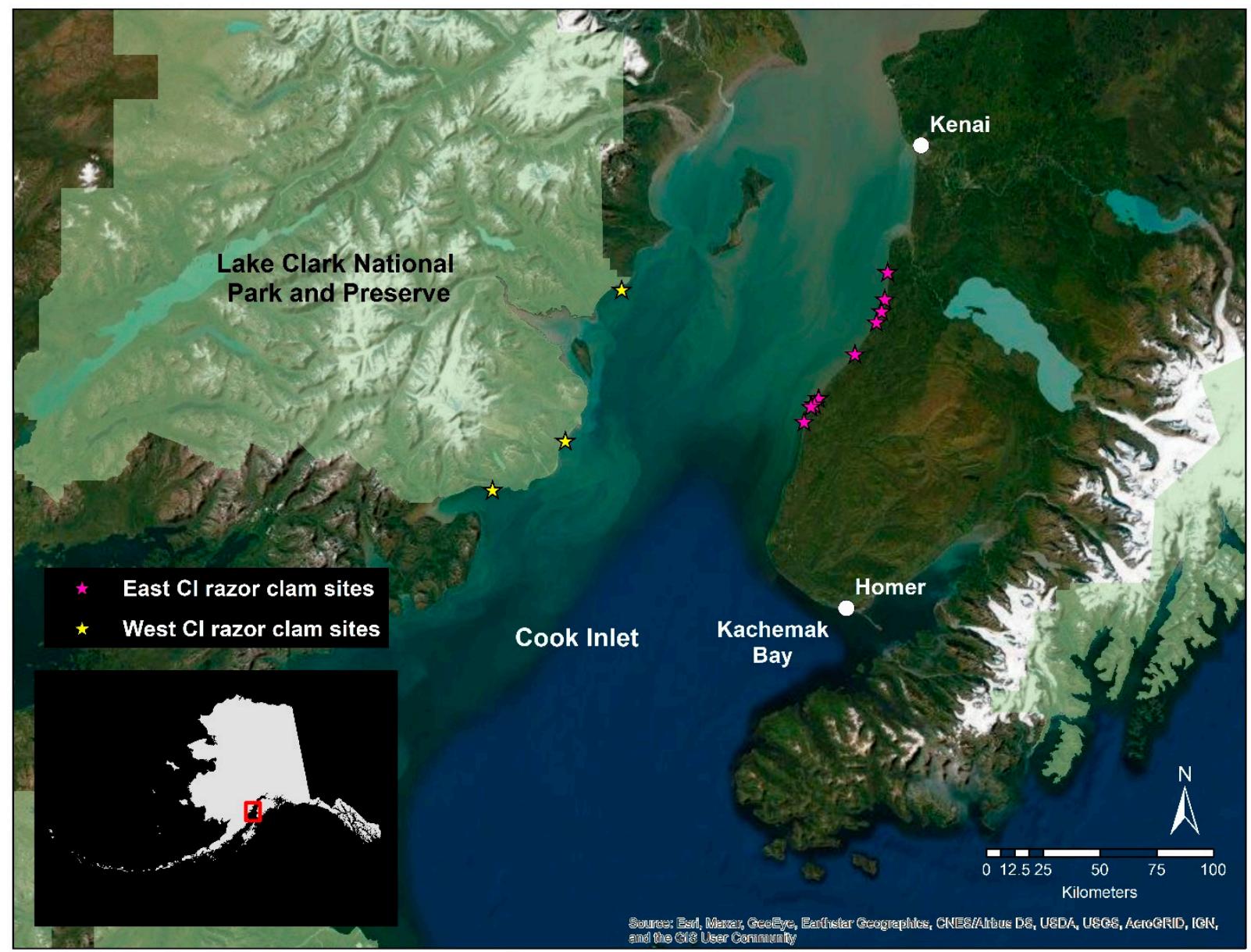

Figure 1. Razor clam sampling sites in ECI (pink stars) and WCI (yellow stars), Alaska. Sites were sampled during 2015 and 2016. ECI sites north to south: Cohoe, Clam Gulch North, Clam Gulch South, North Oil Pad Access, South Oil Pad Access, Ninilchik North, Ninilchik South, Ninilchik Bar, Deep Creek. WCI sites north to south: Polly Creek, Silver Salmon Creek, and Chinitna Bay.

\subsection{Real-Time PCR}

Real-time PCR reactions for the individual, razor clam-specific reference genes (18S and Elongation Factor Alpha-1 (EF1a)) and genes of interest were run in separate wells. Briefly, $1 \mu \mathrm{L}$ of cDNA was added to a mix containing $12.5 \mu \mathrm{L}$ of QuantiTect Fast SYBR Green ${ }^{\circledR}$ Master Mix [5 mM Mg 2+] (Qiagen, Valencia, CA, USA), $0.5 \mu \mathrm{L}$ each of forward and reverse sequence specific primers (Invitrogen, Carlsbad, CA, USA), and $10.5 \mu \mathrm{L}$ of RNase-free water; total reaction mixture was $25 \mu \mathrm{L}$. The reaction mixture cDNA samples for each gene of interest and reference genes were loaded into Fast 96-well plates in duplicate and sealed with optical sealing tape (Applied Biosystems, Foster City, CA, USA). 
Reaction mixtures that contained water, but no cDNA, were used as negative controls. Data are reported as cycle threshold $\left(\mathrm{C}_{\mathrm{T}}\right)$ crossing values; lower values indicate higher levels of expression.

\subsection{Calculation}

The stability of both reference genes was evaluated and ranked using the web-based analysis tool RefFinder (https:/ / www.heartcure.com.au/reffinder/; accessed on OctoberDecember 2020) [57]. The more stable reference gene was selected for use in normalization of the five genes of interest. We used generalized linear mixed models (GLMM) within the LMER4 package in $\mathrm{R}$ version 3.6.1 to test for differences between areas and among sites on the east and west sides of Cook Inlet. The random effect included a site by year interaction to account for site level and interannual variation. Models for each gene expression were fit separately, and we performed post hoc Tukey tests to assess the differences between the means. We also used GLMM to obtain gene expression values for each of the twelve sites, retaining only year as a random effect. We again performed post hoc Tukey tests to make inferences about site-level differences. We show these results using boxplots constructed in R. As neither age nor length affected expression levels in a previous study on razor clams in LACL utilizing the same genes, neither were included in these analyses [37]. We assessed relationships among gene expression levels using Pearson correlations (NCSS, Statistical and Power Analysis Software, Kaysville, UT, USA).

\section{Results}

Over 2 years, approximately 20 Pacific razor clams were collected from each site. The expression levels of five genes of interest and two reference genes were assessed in a total of 230 razor clams. The means and confidence intervals for each site are presented in Table 2. Analyses directed at identifying differences between ECI and WCI, that corrected for inter-site and interannual variation, revealed no differences between the east and west sides of Cook Inlet (Figure 2). Analysis of individual sites revealed significant differences among sites for all genes (Table 2 and Figure 3); however, the magnitude of differences among sites was small, and no consistent patterns were observed. Correlations among the gene expression levels were statistically significant $(p<0.05)$ and positive but low (ranging from 0.16 to 0.71 ). Relatively strong correlations were found between CaM and PPIA (0.71), and between HSP70 and HSP90 (0.61). No correlation was observed between CaM and either HSP70 or HSP90.

Table 2. Mean target gene expression levels ( $C_{T}$ values) followed by $95 \%$ confidence intervals in parentheses for sites in East (ECI) and West (WCI) Cook Inlet. Letters indicate statistical differences; sites sharing a letter did not differ statistically based on post hoc testing (see also Figure 3). Note: smaller mean values indicate higher levels of expression. A total of 20 samples were analyzed from each site except Deep Creek, which had only 10 samples collected in 2016. Gene names and functions are in Table 1.

\begin{tabular}{|c|c|c|c|c|c|c|}
\hline Region & Site & CaM & Ferr & HSP70 & HSP90 & PPIA \\
\hline \multirow[t]{7}{*}{ ECI } & Cohoe & $\begin{array}{c}9.03(8.03,10.02) \\
a b c\end{array}$ & $\begin{array}{c}1.93(1.67,2.20) \\
\text { bc }\end{array}$ & $\begin{array}{c}4.81(4.20,5.42) \\
a\end{array}$ & $\begin{array}{c}4.81(4.12,5.49) \\
\mathrm{a}\end{array}$ & $\begin{array}{c}9.04(8.62,9.46) \\
a\end{array}$ \\
\hline & $\begin{array}{l}\text { Clam Gulch } \\
\text { North }\end{array}$ & $\begin{array}{c}9.21(8.22,10.20) \\
a b\end{array}$ & $\begin{array}{c}1.39(1.13,1.65) \\
a b\end{array}$ & $\begin{array}{c}5.91(5.30,6.52) \\
b\end{array}$ & $\begin{array}{c}6.13(5.45,6.82) \\
b\end{array}$ & $\begin{array}{c}8.98(8.56,9.40) \\
a\end{array}$ \\
\hline & Clam Gulch & $9.58(8.58,10.57)$ & $2.14(1.87,2.40)$ & $5.33(4.72,5.94)$ & $4.67(3.99,5.35)$ & $8.65(8.24,9.07)$ \\
\hline & South & $\mathrm{a}$ & $\mathrm{c}$ & $\mathrm{ab}$ & $\mathrm{a}$ & $\mathrm{ab}$ \\
\hline & $\begin{array}{l}\text { North Oil Pad } \\
\text { Access }\end{array}$ & $\begin{array}{c}9.14(8.14,10.13) \\
a b c\end{array}$ & $\begin{array}{c}1.48(1.21,1.74) \\
\mathrm{ab}\end{array}$ & $\begin{array}{c}4.89(4.28,5.50) \\
\mathrm{a}\end{array}$ & $\begin{array}{c}4.68(3.99,5.36) \\
a\end{array}$ & $\begin{array}{c}8.86(8.44,9.28) \\
a b\end{array}$ \\
\hline & South Oil Pad & $8.34(7.35,9.34)$ & $1.64(1.38,1.91)$ & $5.01(4.40,5.62)$ & $4.40(3.72,5.09)$ & $8.16(7.74,8.58)$ \\
\hline & Access & $\mathrm{bc}$ & $a b c$ & $\mathrm{ab}$ & $\mathrm{a}$ & $\mathrm{ab}$ \\
\hline
\end{tabular}


Table 2. Cont.

\begin{tabular}{|c|c|c|c|c|c|c|}
\hline Region & Site & CaM & Ferr & HSP70 & HSP90 & PPIA \\
\hline & Ninilchik North & $\begin{array}{c}9.25(8.26,10.25) \\
a b\end{array}$ & $\begin{array}{c}1.49(1.23,1.75) \\
a b\end{array}$ & $\begin{array}{c}5.23(4.62,5.83) \\
a b\end{array}$ & $\begin{array}{c}4.61(3.92,5.29) \\
a\end{array}$ & $\begin{array}{c}8.33(7.91,8.75) \\
a b\end{array}$ \\
\hline & Ninilchik South & $\begin{array}{c}8.28(7.28,9.27) \\
\text { bc }\end{array}$ & $\begin{array}{c}1.40(1.14,1.66) \\
\mathrm{ab}\end{array}$ & $\begin{array}{c}5.07(4.46,5.68) \\
a b\end{array}$ & $\begin{array}{c}4.85(4.17,5.54) \\
\text { a }\end{array}$ & $\begin{array}{c}8.13(7.71,8.55) \\
a b\end{array}$ \\
\hline & Ninilchik Bar & $\begin{array}{c}8.43(7.43,9.42) \\
a b c\end{array}$ & $\begin{array}{c}1.53(1.27,1.79) \\
\mathrm{ab}\end{array}$ & $\begin{array}{c}5.54(4.93,6.15) \\
a b\end{array}$ & $\begin{array}{c}4.95(4.27,5.64) \\
\mathrm{ab}\end{array}$ & $\begin{array}{c}8.22(7.81,8.64) \\
a b\end{array}$ \\
\hline & Deep Creek & $\begin{array}{c}8.68(7.63,9.74) \\
a b c\end{array}$ & $\begin{array}{c}1.38(1.02,1.75) \\
a b\end{array}$ & $\begin{array}{c}4.78(4.06,5.51) \\
a b\end{array}$ & $\begin{array}{c}4.42(3.57,5.27) \\
\text { a }\end{array}$ & $\begin{array}{c}8.38(7.79,8.97) \\
\mathrm{ab}\end{array}$ \\
\hline & All ECI & $8.87(8.64,9.10)$ & $1.61,(1.51,1.71)$ & $5.21(5.05,5.37)$ & $4.87(4.67,5.07)$ & $8.54(8.37,8.70)$ \\
\hline \multirow[t]{4}{*}{ WCI } & Polly Creek & $\begin{array}{c}7.92(6.92,8.91) \\
\text { C }\end{array}$ & $\begin{array}{c}1.25(0.98,1.51) \\
\mathrm{a}\end{array}$ & $\begin{array}{c}4.87(4.26,5.48) \\
a\end{array}$ & $\begin{array}{c}5.54(4.85,6.22) \\
a b\end{array}$ & $\begin{array}{c}8.00(7.58,8.42) \\
b\end{array}$ \\
\hline & Silver Salmon & $\begin{array}{c}8.49(7.50,9.49) \\
\text { abc }\end{array}$ & $\begin{array}{c}1.46(1.20,1.72) \\
\mathrm{ab}\end{array}$ & $\begin{array}{c}5.17(4.56,5.78) \\
\mathrm{ab}\end{array}$ & $\begin{array}{c}5.39(4.70,6.07) \\
a b\end{array}$ & $\begin{array}{c}8.58(8.16,9.00) \\
\mathrm{ab}\end{array}$ \\
\hline & Chinitna Bay & $\begin{array}{c}8.55(7.56,9.55) \\
\text { abc }\end{array}$ & $\begin{array}{c}1.20(0.93,1.46) \\
a\end{array}$ & $\begin{array}{c}4.66(4.05,5.27) \\
\mathrm{a}\end{array}$ & $\begin{array}{c}4.88(4.19,5.56) \\
a\end{array}$ & $\begin{array}{c}8.48(8.06,8.90) \\
a b\end{array}$ \\
\hline & All WCI & $8.32(8.15,8.49)$ & $1.30(1.17,1.43)$ & $4.90(4.63,5.17)$ & $5.27(4.98,5.56)$ & $8.35(8.20,8.50)$ \\
\hline
\end{tabular}

\section{East Cook Inlet West Cook Inlet}

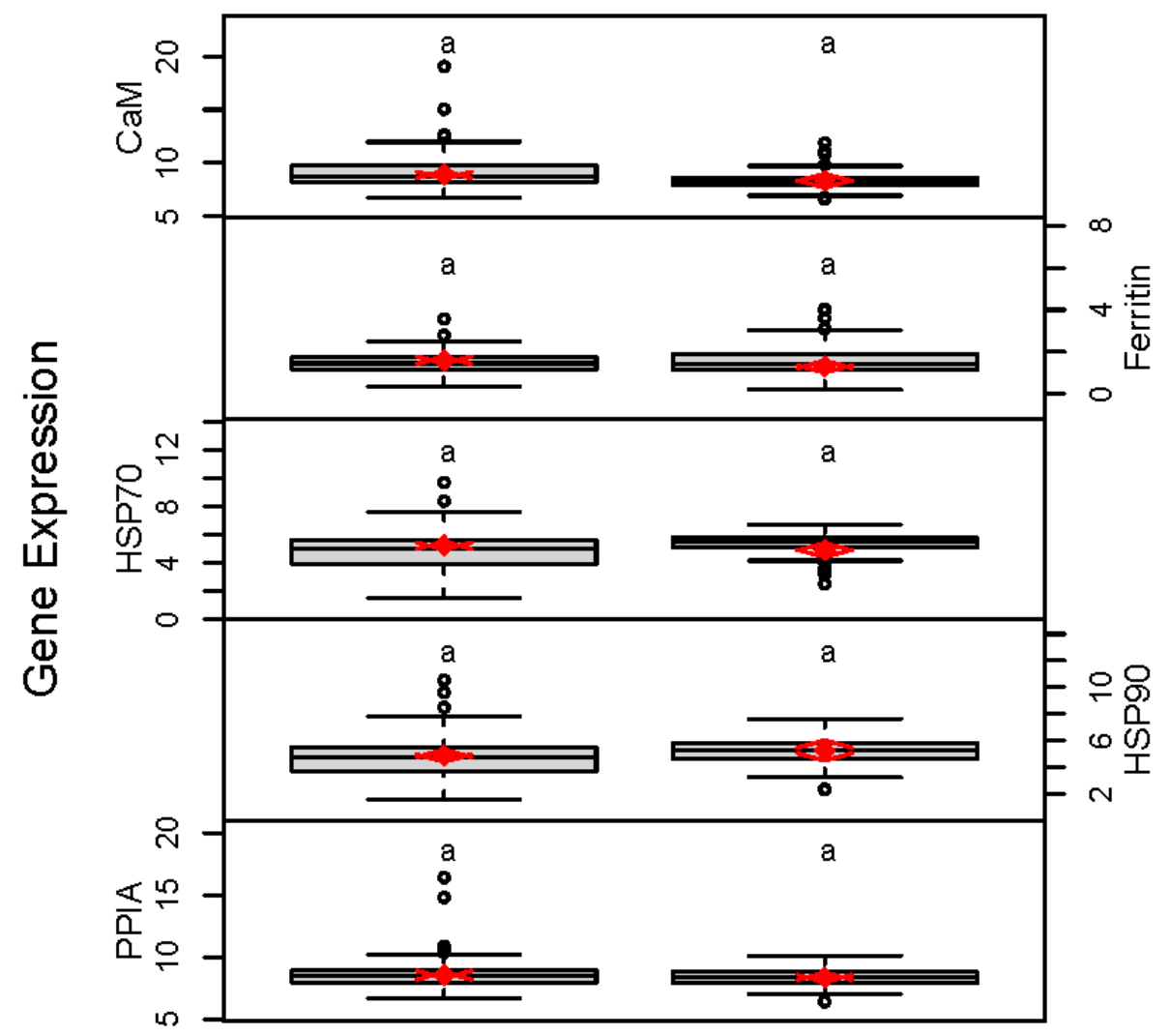

Figure 2. Region-level boxplots of data $\left(C_{T}\right.$ values) from five different gene expression assays performed on Pacific razor clams collected at three sites in WCI and nine sites in ECI. Random effects model results are denoted by red diamonds (mean) and red arrows (95\% confidence intervals). Sites sharing a letter did not differ statistically based on post hoc testing. Analyzed by location (WCI vs. ECI), gene expression did not differ significantly. Note: smaller numbers indicate higher levels of expression. 


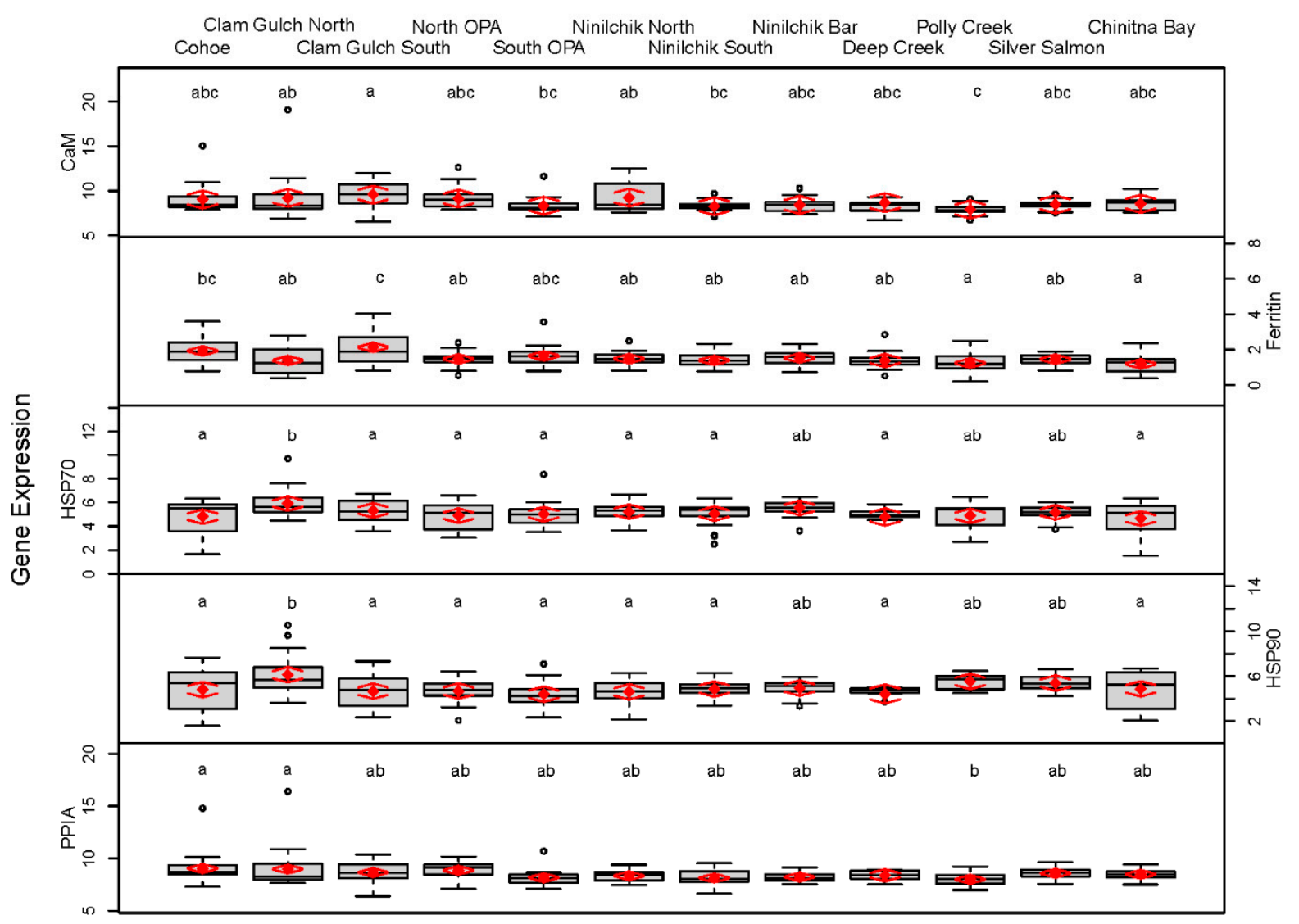

Figure 3. Site-level boxplots of data $\left(\mathrm{C}_{\mathrm{T}}\right.$ values) from gene expression assays on five genes, performed on Pacific razor clams collected at nine sites in ECI (Cohoe-Deep Creek) and three sites in WCI (Polly Creek-Chinitna Bay). Random effects of model results are denoted by red diamonds (mean) and red arrows ( $95 \%$ confidence intervals). Sites sharing a letter did not differ statistically based on post hoc testing. Note: smaller numbers indicate higher levels of expression. See Table 1 for gene names and functions.

\section{Discussion}

Currently, causes of the Pacific razor clam decline in ECI are not well understood, but the fishery has been restricted or closed since 2013 due to low abundance [13]. Sampling conducted in 2020 indicates that while juvenile recruitment at ECI sites was similar to historical averages, adult mortality across sites was relatively high [11]. In contrast, razor clams in WCI continue to support commercial and recreational fisheries, and although declines in sport, personal and commercial harvests have been documented recently, they appear to reflect lower harvest efforts as opposed to declining stocks [3]. In an effort to understand potential pressures influencing razor clam abundance in $\mathrm{WCI}$ and $\mathrm{ECI}$, we used gene expression to assess the molecular responses of razor clams to their environments. Gene expression, which includes the study of transcriptomes and their function (http:/ / www.nature.com/subjects/transcriptomics; [32,58]), is an evolving approach to biomarker monitoring. Little is known about the genomic responses of Pacific razor clams to environmental stimuli. Recently, we completed the first study using gene expression diagnostics as a monitoring tool for the Pacific razor clam, including clams sampled from WCI [37]. Because of recognized and potential differences in clam demographics and population status between ECI and WCI [3], we anticipated finding population differences in gene expression in Pacific razor clams.

Differences among populations are often attributed to a variety of drivers, including those that elicit a physiological response (e.g., parasites, disease, contaminants, nutrient availability), and those that may not (e.g., habitat degradation, predation) $[59,60]$. For example, parasite infections can reduce growth, overall condition and reproduction, and 
cause mortality in bivalves [19,61], and parasites including trematodes and Haplosporidium spp. have been found in razor clams in Alaska [62]. A study in 2010 identified parasites in many razor clams sampled from a site in ECI (Clam Gulch) [63]. However, parasite levels in Pacific razor clams in WCI have not been reported. Pathogens are also known to play roles in shaping ecosystems [37]. However, nuclear inclusion X (NIX), a pathogen of serious concern in other Pacific razor clam populations in the Pacific Northwest (Washington and Oregon) is rare in Alaska [64] and in fact, NIX was not identified in samples from our sites in a parallel study conducted in 2019 [65]. Contaminants are widely recognized as potentially important stressors on marine ecosystems [66]. However, while not directly measured in razor clam tissues, contaminants are not thought to be an issue in Cook Inlet, based on other invertebrate data from the northern Gulf of Alaska [67].

There are oceanographic (both physical and biological) and geomorphological differences between ECI and WCI $[13,16]$. The amount and topography of razor clam habitat differs between ECI and WCI, with WCI having significantly larger razor clam beaches. However, based on ShoreZone ${ }^{\circledR}$ sediment type, the exposure and oil residency index values indicate almost no difference between ECI and WCI or among individual sites [15]. The similarity in physical structure and exposure across the sites is to be expected. Unlike mussels, razor clams require specific habitat features to flourish and are not ubiquitous across the north Pacific [1]. Dynamic attributes, such as temperature and salinity gradients, do exist between the east and west sides of the Inlet [16]. The timing of algal blooms, as a source of nutrients, differs between the east and west coasts of Cook Inlet. The major factors responsible for initiating blooms in lower Cook Inlet are water stratification, incident radiation, and water clarity $[17,68]$. Favorable conditions for the bloom occur first in Kachemak Bay, with a longer residence time and lower mixing rates, permitting surface water to warm in the spring and retain phytoplankton populations at high concentrations $[17,68]$. The major component of lower east Cook Inlet water originates in the Gulf of Alaska and does not contain the heavy load of suspended inorganic particles present in the upper Cook Inlet water which dominates the western side.

With differential environmental pressures such as these, we might have expected to see variation in expression of the target genes between WCI and ECI. However, we found no significant differences in expression levels of genes between WCI and ECI when we compared the areas with sites grouped together. Furthermore, when we compared expression levels from WCI and ECI with levels from Pacific razor clams in Katmai National Park (samples collected in same season and year; data from [37]), clams from Katmai had significantly higher expression of CaM, PPIA, and Ferr, and significantly lower expression of HSP70 than clams from WCI or ECI. The implications are that WCI and ECI are relatively similar in terms of environmental drivers such as pathogens, ocean acidification, contaminants, and nutrient availability pressures, while pressures at Katmai, including pathogens and nutrient availability, apparently differ. The contrast between razor clams sampled from Katmai with those from other areas (WCI and ECI) supports the diagnostic value of the genes included in our panel. The significant correlations seen among the genes in our panel suggest concurrent responses to environmental conditions. It should be noted that our sampling occurred only in June and July, which are generally months of elevated primary productivity compared to other times of the year [69].

A potentially strong driver of environmental differences within Cook Inlet is the convergence of freshwater discharges and the Alaska coastal current, which supports higher nutrient availability important for growth of sessile organisms [13]. However, ocean current effects and other processes are not necessarily uniform across sites. For example, Ninilchik and Clam Gulch have been identified in previous studies as differing in mortality, recruitment, and growth rates of Pacific razor clams $[3,6,13,63]$. As discussed by Blackmon [10], bivalve growth rates vary both temporally and spatially, and these patterns may relate to physical and environmental drivers, such as temperature, salinity, sediments, and phytoplankton [70-75]. 
Seasonal distribution of sea ice within Cook Inlet may also play a role in clam population status. Warming ocean temperatures and a rapidly changing climate, particularly in high latitudes, may decrease the seasonal ice present in Cook Inlet. This could result in greater disturbance to shorelines if ice is more mobile and scours the shorelines to a greater extent. Alternatively, with less ice, the shorelines may be more vulnerable to storm surges, impacting habitat, and clam survival. In either case, changes in ice cover could affect single sites, as opposed to Inlet-wide disturbances.

During our sampling period, a marine heatwave ("The Blob"), unprecedented in spatial extent and duration, occurred in the north Pacific [76]. Temperature differences that might have existed at the site level and could contribute to variation in growth or other metrics were likely dampened by this large-scale climactic event $[77,78]$.

When all sites were analyzed individually, we found statistically significant expression differences among genes at all sites (Figure 3). However, the expression differences were small. Varying levels of expression within or among groups or individuals may be normal responses to stimuli and while statistically significant, are likely not biologically relevant [37]. Continuing studies, including controlled exposures, will clarify the biological relevance of differences in gene expression in Pacific razor clams $[37,79]$.

Little is known about the genetic makeup of Pacific razor clams in comparison with other commercially harvested invertebrate species, and our initial research suggested that razor clams are highly genetically divergent from other bivalves. However, the genes targeted in our study have been shown to respond to stressors, both with the closely related Chinese razor clam (Sinonovacula constricta) and other bivalves [38-46]. In a previous study we determined this target gene panel to be effective at identifying differences between Pacific razor clam populations in seemingly pristine areas [37]. Our targeted expression panel enabled identification of differences in nutrient/energy availability as well as contaminant and pathogen presence between two national parks and among sites [37]. Specifically, the targeted panel enhanced our ability to understand the potential input of both large- and fine-scale processes and pointed to a higher quantity or quality of nutrients at Lake Clark National Park (LACL) in comparison with Katmai National Park (KATM), a higher pathogen response at KATM in comparison with LACL, and a higher response to contaminants at some individual sites than at others.

Although expression studies generally focus on genes that are differentially transcribed among groups, a finding that expression does not vary among groups is also informative. For example, similar gene expression profiles contributed to a body of evidence that pointed to predation as the leading cause of population decline in Southwest Alaska sea otters $[80,81]$. With no notable expression differences found between WCI and ECI clams, there are alternative conclusions to consider: (1) differing environmental conditions exist that affect expression but were not detected by our gene panel or (2) pressures such as changes in habitat or predation may be impacting razor clam populations in ECI, but do not elicit a physiological response in the clams and therefore would not be detected in this study.

The importance of physical and oceanographic drivers to the small-scale spatial structuring of some intertidal species likely varies with the extent of top-down pressures $[82,83]$. Possible top-down drivers of Pacific razor clam abundance include human harvest and predation by animals such as brown bears [21,84] and sea otters [22]. Human overharvest has not been implicated in the decline of razor clams in ECI, primarily due to relatively low harvest rates [9] and lack of recovery after several years of fishery restrictions and subsequent closure [3]. Previous studies along the Katmai National Park and Preserve coast, just south of LACL, have observed bears consuming intertidal resources, but the level of predation is not thought to be sufficient to impact bivalves at the population level [84]. Bear predation is not thought to be a factor driving clam abundance at ECI, as bears are rarely seen on ECI beaches. In contrast, sea otters are widely recognized for their role in structuring nearshore marine ecosystems [85-90]. The sea otter is a keystone predator [85] whose historical range encompassed the entire coastal north Pacific before 
they were almost extirpated, except for small remnant populations, due to the maritime fur harvest [91]. International protections beginning in 1911 have allowed sea otters to reoccupy habitats [92] where invertebrate populations flourished in their absence. Through predation, a decrease in the abundance of select marine invertebrates is often an outcome of sea otter recolonization, including species important to both commercial, subsistence, and recreational fisheries [93-98]. The sea otters' diet is dominated by a variety of clam species throughout the Gulf of Alaska $[59,88,99,100]$. Studies conducted in Washington, where sea otters have recently expanded into areas with high densities of Pacific razor clams, report sea otter diets consisting largely of razor clams [22]. The decline of razor clams in ECI may result from the expansion of the sea otter population moving north from Kachemak Bay along ECI (Figure 4). Aerial surveys conducted in 2002 estimated the abundance of sea otters in ECI (excluding Kachemak Bay) to be approximately 962 animals [101]. By 2017, the ECI abundance estimate for sea otters (excluding Kachemak Bay) was 3164 animals [23], a $230 \%$ increase. Estimates for the WCI area have also increased during the same time frame (6918 sea otters in 2002; 10,737 in 2017; a 55\% increase; [101]); however, in 2017, sea otters had not expanded their range north of Kamishak Bay ([23]; Figure 4), where expanses of razor clam beaches and harvests persist. While not directly measured in this study, the distribution and abundance of sea otters are different between the two sides of Cook Inlet [23] and are potentially drivers in the population status of razor clams that deserve further investigation.

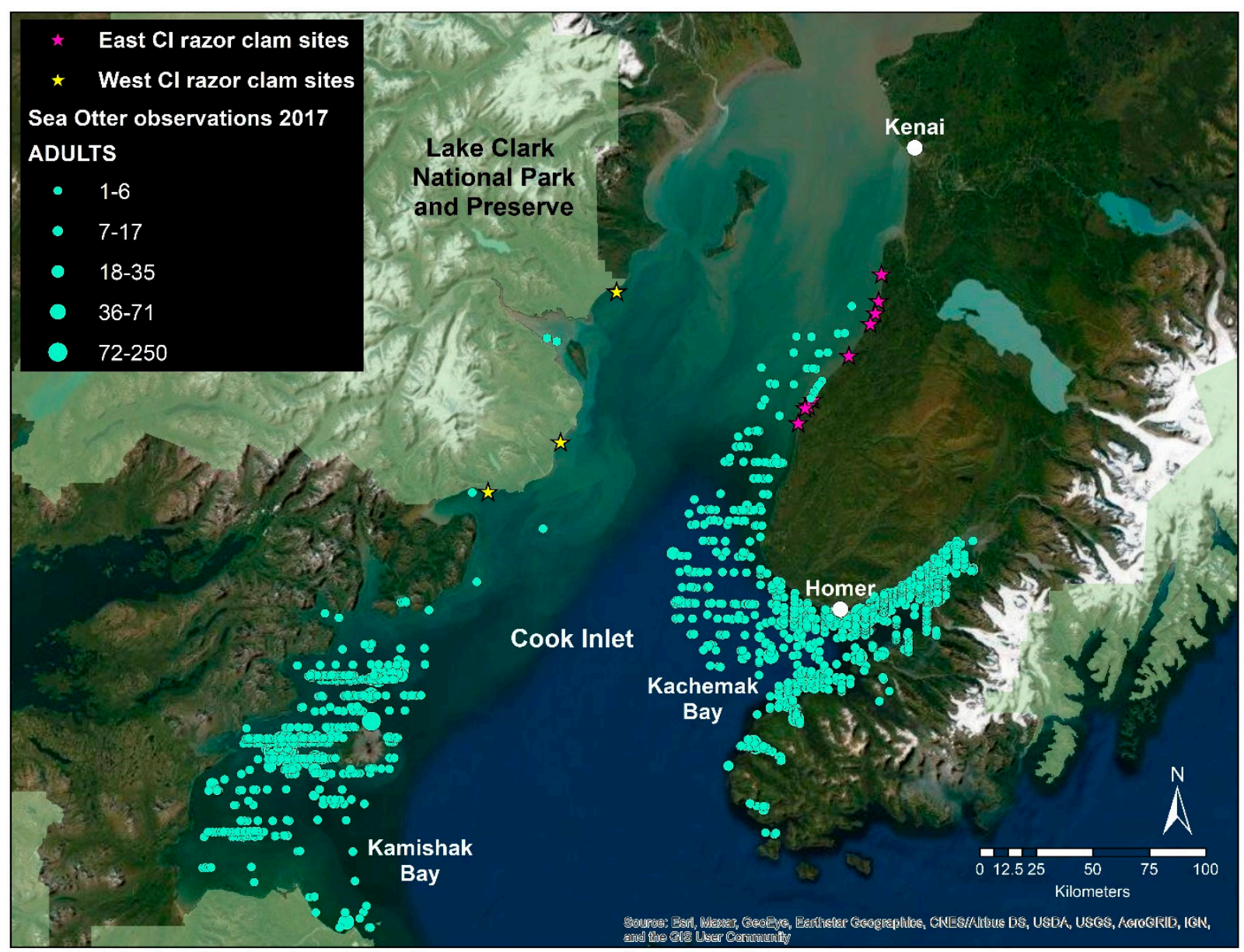

Figure 4. Sea otter abundance and distribution across Lower Cook Inlet, 2017 [23]. Sea otters are represented by light green dots. Dot size is representative of adult group size observed. East razor clam sites are represented by purple stars while west razor clam sites are represented by yellow stars. 


\section{Conclusions}

This study introduces an application of new technology (Pacific razor clam gene expression; [37]) to investigate an ecosystem-level problem. The genes we evaluated generally respond to a wide variety of environmental stressors commonly associated with coastal marine habitats. Although there may be environmental conditions that differ among our study sites, the conditions likely do not account for the divergent population trends in razor clams. Our results suggest that pathogens, contaminants, nutrients, or physiological stress are not driving population abundance at the scale of Cook Inlet. We did not measure direct predation pressure exerted by sea otters on our sampled beaches. Nevertheless, we know that when sea otters newly recolonize an area, significant declines in their invertebrate prey populations will predictably follow. Based on the most recent aerial survey data from Cook Inlet, sea otters have developed a significant presence along the ECI coastline and are virtually absent at our study sites along the WCI coastline [23]. However, surveys flown along the WCI coastline during the summer of 2019 observed higher sea otter abundance, indicating sea otters are moving northward along the west side of Cook Inlet [102]. The contrast in sea otter presence between ECI and WCI suggests they may be a contributing cause of the razor clam decline in the east and if so, suggests a similar outcome for razor clams to the west if sea otter expansion continues.

The extent that various drivers structure razor clam communities at both small and large spatial scales warrants further examination. To improve our ability to use gene expression to attribute specific environmental drivers to detrimental population outcomes for Pacific razor clam and other bivalve species, controlled laboratory exposure studies with whole transcriptome responses are advised. Additionally, consideration of the cascading effects of climate change should complement gene expression methods in evaluating trends in populations. Monitoring the expansion of sea otters as they reoccupy habitat along WCI will be important to determine the role of sea otters in structuring invertebrate populations and aid management of the clam harvest by anticipating and responding to ecological change.

Author Contributions: Conceptualization, H.A.C., L.B., B.E.B., K.L.C., T.E.H. and B.P.; methodology, L.B., B.E.B. and S.W.; software, T.L.W.; validation, T.L.W. and L.B.; formal analysis, T.L.W.; investigation, H.A.C., L.B, B.E.B., K.L.C., S.W. and B.P.; resources, H.A.C., L.B., S.W. and M.B.; data curation, S.W.; writing—original draft preparation, H.A.C., L.B., B.E.B., T.L.W., M.B., K.L.C. and B.P.; writing-review and editing, H.A.C., L.B., B.E.B., T.L.W., M.B., K.L.C., S.W., T.E.H. and B.P.; visualization, H.A.C. and T.L.W.; project administration, H.A.C., B.P.; funding acquisition, H.A.C. and B.P. All authors have read and agreed to the published version of the manuscript.

Funding: This work was supported by the National Park Service Foundation and the National Park Service. Alaska Department of Fish and Game provided support for sample collection at ECI. Lake Clark National Park and Preserve provided support for sample collection in WCI. Any use of trade, firm, or product names is for descriptive purposes only and does not imply endorsement by the U.S. Government. The data that support the findings of this study are available from the corresponding author upon reasonable request.

Institutional Review Board Statement: Field protocols and collections of Pacific razor clams were reviewed and approved by the State of Alaska Department of Fish and Game (Permit numbers CF-15-088 and CF-16-089).

Informed Consent Statement: Not applicable.

Data Availability Statement: Data available upon request.

Acknowledgments: We thank Jim Bodkin for overall field and technical support as well as a thorough review of this paper. We also thank Timothy Blackmon for Cook Inlet sample collections. John Muir Institute of the Environment and Center for Aquatic Biology and Aquaculture at the University of California at Davis provided office and laboratory space.

Conflicts of Interest: The authors declare no conflict of interest. 


\section{References}

1. Bishop, M.; Powers, S. Restoration of Razor Clam (Siliqua patula) Populations in Southeastern Prince William Sound, Alaska: Integrating Science, Management and Traditional Knowledge in the Development of a Restoration Strategy; Final Report; Alaska Department of Fish and Game: Anchorage, AK, USA, 2003.

2. MacKenzie, C.L., Jr.; Burrell, V.G., Jr. Trends and status of molluscan fisheries in North and Central America and Europe-A synopsis. In The History, Present Condition, and Future of the Molluscan Fisheries of North and Central America and Europe; MacKenzie, C.L., Jr., Burrell, V.G., Jr., Rosenfield, A., Hobart, W.L., Eds.; Tech Rep. 127; U.S. Department of Commerce, NOAA: Washington, DC, USA, 1997; pp. 1-15.

3. Booz, M.D.; Schuster, M.; Dickson, H.I.; Kerkvliet, C.M. Sport Fisheries in the Lower Cook Inlet Management Area, 2017-2018, with Updates for 2016; Fishery Management Report No. 19-20; Alaska Department of Fish and Game: Anchorage, AK, USA, 2019.

4. Shields, P.; Dupuis, A. Upper Cook Inlet Commercial Fisheries Annual Management Report, 2013; Fishery Management Report No. 13-49; Alaska Department of Fish and Game: Anchorage, AK, USA, 2013.

5. Dyson, K.; Huppert, D.D. Regional economic impacts of razor clam beach closures due to harmful algal blooms (HABs) on the Pacific Coast of Washington. Harmful Algae 2010, 9, 264-271. [CrossRef]

6. Szarzi, N.J.; Kerkvliet, C.M.; Failor, B.J.; Booz, M.D. Recreational Fisheries in the Lower Cook Inlet Management Area, 2008-2010, with Updates for 2007; Fishery Management Report No. 10-38; Alaska Department of Fish and Game: Anchorage, AK, USA, 2010.

7. ADF\&G. Personal Use Fishing Emergency Order: 2-RCL-7-10-14; Alaska Department of Fish and Game: Anchorage, AK, USA, 2015.

8. Kerkvliet, C.M.; Booz, M.D.; Blackmon, T.J.; Hansen, P.A. Eastside Cook Inlet Razor Clam Stock Assessment, 2009-2015; Alaska Department of Fish and Game, Fishery Data Series No. 21-04; Alaska Department of Fish and Game: Anchorage, AK, USA, 2021.

9. Szarzi, N.J.; Hansen, P.A. Harvest, Abundance, Age and Length Characteristics of Razor Clams from Eastern Cook Inlet Beaches 2004-2008; Fishery Data Series No. 09-03; Alaska Department of Fish and Game: Anchorage, AK, USA, 2009.

10. Kerkvliet, C.M.; Booz, M.D. Cook Inlet Razor Clam Study, 2014; Regional Operational Plan ROP.SF.2A.2014; Alaska Department of Fish and Game: Anchorage, AK, USA, 2015.

11. ADF\&G. Personal Use Emergency Order No. 2-RCL-7-04-21; Alaska Department of Fish and Game: Anchorage, AK, USA, 2020.

12. Kerkvliet, C.M.; Booz, M.D. Operational Plan: Cook Inlet Razor Clam Study, 2015; Alaska Department of Fish and Game, Regional Operational Plan ROP.SF.2A.2016.02; Alaska Department of Fish and Game: Anchorage, AK, USA, 2016.

13. Blackmon, T.J. Growth of Pacific Razor Clams in Cook Inlet, Alaska. Master's Thesis, Alaska Pacific University, Anchorage, AK, USA, 2020.

14. Jones, T.; Saupe, S.; Iken, K.; Konar, B.; Venator, S.; Lindeberg, M.; Coletti, H.; Pister, B.; Reynolds, J.; Haven, K. Assessment of Nearshore Communities and Habitats: Lower Cook Inlet Nearshore Ecosystem 2015-2018; OCS Study BOEM 2019-075; US Department of the Interior, Bureau of Ocean Energy Management: Anchorage, AK, USA, 2019; p. 221.

15. Harper, J.R.; Morris, M.C. ShoreZone Mapping Protocol for the Gulf of Alaska (Ver 1.0); CORI Project: 02-33 EVOS Project: 030641; Exxon Valdez Trustee Council: Anchorage, AK, USA, 2004.

16. Okkonen, S.; Pegau, S.; Saupe, S. Seasonality of Boundary Conditions for Cook Inlet, Alaska; Coastal Marine Institute, University of Alaska, Minerals Management Service, Department of the Interior, and the School of Fisheries \& Ocean Sciences: Fairbanks, AK, USA, 2009.

17. Vandersea, M.W.; Kibler, S.R.; Tester, P.A.; Holderied, K.; Hondolero, D.E.; Powell, K.; Baird, S.; Doroff, A.; Dugan, D.; Litaker, R.W. Environmental Factors Influencing the Distribution and Abundance of Alexandrium Catenella in Kachemak Bay and Lower Cook Inlet, Alaska. Harmful Algae 2018, 77, 81-92. [CrossRef]

18. Matozzo, V.; Marin, M.G. Bivalve immune responses and climate changes: Is there a relationship? ISJ Invert. Surviv. J. 2011, 8, 70-77.

19. Soudant, P.; Chu, F.L.; Volety, A. Host-parasite interactions: Marine bivalve molluscs and protozoan parasites, Perkinsus species. J. Invertebr. Pathol. 2013, 114, 196-216. [CrossRef] [PubMed]

20. Siegert, D. Trophic Structure of Rocky Intertidal Communities in Contrasting High-Latitude Environments. Master's Thesis, University of Alaska, Fairbanks, AK, USA, 2020.

21. Smith, T.; Partridge, S. Dynamics of intertidal foraging by coastal brown bears in southwestern Alaska. J. Wildl. Manag. 2004, 68, 233-240. [CrossRef]

22. Hale, J.R.; Laidre, K.L.; Tinker, M.T.; Jameson, R.J.; Jeffries, S.J.; Larson, S.E.; Bodkin, J.L. Influence of occupation history and habitat on Washington sea otter diet. Mar. Mammal. Sci. 2019, 35, 1369-1395. [CrossRef]

23. Garlich-Miller, J.L.; Esslinger, G.G.; Weitzman, B.P. Aerial Surveys of Sea Otters (Enhydra lutris) in Lower Cook Inlet, Alaska, May 2017; Marine Mammals Management Technical Report: MMM 2018-01; U.S. Fish and Wildlife Service: Anchorage, AK, USA, 2018.

24. Harper, P.; McCarthy, L.A. (Eds.) Brown Bear Management Report of Survey and Inventory Activities 1 July $2012-30$ June 2014; Management Report ADF\&G/DWC/SMR-2015-1; Alaska Department of Fish and Game, Species: Juneau, AK, USA, 2015.

25. Evans, T.G.; Hofmann, G.E. Defining the Limits of Physiological Plasticity: How Gene Expression Can Assess and Predict the Consequences of Ocean Change. Phil. Trans. R. Soc. B 2012, 367, 1733-1745. [CrossRef]

26. Bourlat, S.J.; Borja, A.; Gilbert, J.; Taylor, M.I.; Davies, N.; Weisberg, S.B.; Griffith, J.F.; Lettieri, T.; Field, D.; Benzie, J.; et al. Genomics in Marine Monitoring: New Opportunities for Assessing Marine Health Status. Mar. Pollut. Bull. 2013, 74, 19-31. [CrossRef] 
27. Strader, M.E.; Wong, J.M.; Hofmann, G.E. Ocean acidification promotes broad transcriptomic responses in marine metazoans: A literature survey. Front. Zool. 2020, 17, 7. [CrossRef] [PubMed]

28. Suárez-Ulloa, V.; Fernández-Tajes, J.; Manfrin, C.; Gerdol, M.; Venier, P.; Eirín-López, J.M. Bivalve Omics: State of the Art and Potential Applications for the Biomonitoring of Harmful Marine Compounds. Mar. Drugs 2013, 11, 4370-4389. [CrossRef] [PubMed]

29. Lockwood, B.L.; Connor, K.M.; Gracey, A.Y.; Podrabsky, J.E.; Stillman, J.H.; Tomanek, L. The environmentally tuned transcriptomes of Mytilus mussels. J. Exp. Biol. 2015, 218, 1822-1833. [CrossRef]

30. Reid, N.M.; Whitehead, A. Functional genomics to assess biological responses to marine pollution at physiological and evolutionary timescales: Toward a vision of predictive ecotoxicology. Brief. Funct. Genom. 2015, 15, 358-364. [CrossRef]

31. Mancia, A. Chapter 11-New Technologies for Monitoring Marine Mammal Health. In Marine Mammal Ecotoxicology; Fossi, M.C., Panti, C., Eds.; Academic Press: Cambridge, MA, USA, 2018; pp. 291-320. [CrossRef]

32. Jax, E.; Wink, M.; Kraus, R.H.S. Avian transcriptomics: Opportunities and challenges. J. Ornithol. 2018, 159, 599-629. [CrossRef]

33. Gleason, L.U. Applications and Future Directions for Population Transcriptomics in Marine Invertebrates. Curr. Mol. Biol. Rep. 2018, 5, 116-127. [CrossRef]

34. Acevedo-Whitehouse, K.; Duffus, A.L.J. Effects of Environmental Change on Wildlife Health. Phil. Trans. R. Soc. B 2009, 364, 3429-3438. [CrossRef]

35. McLoughlin, K.; Turteltaub, K.; Bankaitis-Davis, D.; Gerren, R.; Siconolfi, L.; Storm, K.; Cheronis, J.; Trollinger, D.; Macejak, D.; Tryon, V.; et al. Limited dynamic range of immune response gene expression observed in healthy blood donors using RT-PCR. Mol. Med. 2006, 12, 185-195. [CrossRef] [PubMed]

36. Poynton, H.C.; Vulpe, C.D. Ecotoxicogenomics: Emerging Technologies for Emerging Contaminants. J. Am. Water Resour. Assoc. 2009, 45, 83-96. [CrossRef]

37. Bowen, L.; Counihan, K.L.; Ballachey, B.; Coletti, H.; Hollmen, T.; Pister, B.; Wilson, T.L. Monitoring nearshore ecosystem health using Pacific razor clams (Siliqua patula) as an indicator species. PeerJ 2020, 8, e8761. [CrossRef]

38. Chen, Z.F.; Wang, H.; Matsumura, K.; Qian, P.Y. Expression of calmodulin and myosin light chain kinase during larval settlement of the barnacle Balanus amphitrite. PLoS ONE 2012, 7, e31337. [CrossRef] [PubMed]

39. Leite, R.B.; Milan, M.; Coppe, A.; Bortoluzzi, S.; dos Anjos, A.; Reinhardt, R.; Saavedra, C.; Patarnello, T.; Cancela, M.; Bargelloni, L. MRNA-Seq and Microarray Development for the Grooved Carpet Shell Clam, Ruditapes decussatus: A Functional Approach to Unravel Host -Parasite Interaction. BMC Genom. 2013, 14, 741. [CrossRef]

40. Li, C.; Li, H.; Su, X. Identification and characterization of a clam ferritin from Sinonovacula constricta. Fish Shellfish Immun. 2011, 30, 1147-1151. [CrossRef]

41. Perrigault, M.; Tanguy, A.; Allam, B. Identification and Expression of Differentially Expressed Genes in the Hard Clam, Mercenaria, in Response to Quahog Parasite Unknown (QPX). BMC Genom. 2009, 10, 377. [CrossRef]

42. Wang, M.; Zhang, D.; Wang, L.; Gai, Y.; Zhou, Z.; Zhang, H.; Song, L. The Molecular Characterization of a Cyclophilin A from Chinese Mitten Crab Eriocheir Sinensis and the Antifungal Activity of Its Recombinant Protein. Electron. J. Biotechnol. 2013, 16. [CrossRef]

43. Cellura, C.; Toubiana, M.; Parrinello, N.; Roch, P. Specific Expression of Antimicrobial Peptide and HSP70 Genes in Response to Heat-Shock and Several Bacterial Challenges in Mussels. Fish Shellfish Immun. 2007, 22, 340-350. [CrossRef]

44. Choi, C.Y.; Min, B.H.; Kim, N.N.; Cho, S.H.; Chang, Y.J. Expression of HSP90, HSP70 mRNA and change of plasma cortisol and glucose during water temperature rising in freshwater adapted black porgy, Acanthopagrus schlegeli. J. Aquacult. 2006, 19, 315-322.

45. Choi, Y.K.; Jo, P.G.; Choi, C.Y. Cadmium Affects the Expression of Heat Shock Protein 90 and Metallothionein MRNA in the Pacific Oyster, Crassostrea Gigas. Comp. Biochem. Phys. C 2008, 147, 286-292. [CrossRef]

46. Gao, Q.; Song, L.; Ni, D.; Wu, L.; Zhang, H.; Chang, Y. cDNA cloning and mRNA expression of heat shock protein 90 gene in the haemocytes of Zhikong scallop Chlamys farreri. Comp. Biochem. Phys. B 2007, 147, 704-715. [CrossRef]

47. Richards, M.; Xu, W.; Mallozzi, A.; Errera, R.M.; Supan, J. Production of Calcium-Binding Proteins in Crassostrea virginica in Response to Increased Environmental $\mathrm{CO}_{2}$ Concentration. Front. Mar. Sci. 2018, 5, 203. [CrossRef]

48. Leprêtre, M.; Almunia, C.; Armengaud, J.; Le Guernic, A.; Salvador, A.; Geffard, A.; Palos-Ladeiro, M. Identification of Immune-Related Proteins of Dreissena Polymorpha Hemocytes and Plasma Involved in Host-Microbe Interactions by Differential Proteomics. Sci. Rep. 2020, 10, 6226. [CrossRef] [PubMed]

49. Zhang, W.Y.; Storey, K.B.; Dong, Y.W. Adaptations to the mudflat: Insights from physiological and transcriptional responses to thermal stress in a burrowing bivalve Sinonovacula constricta. Sci. Total Environ. 2020, 710, 136280. [CrossRef] [PubMed]

50. Lin, X.; Wu, X.; Liu, X. Temperature stress response of heat shock protein 90 (Hsp90) in the clam Paphia undulata. Aquacult. Fish. 2018, 3, 106-114. [CrossRef]

51. Kumar, G.; Ertl, R.; Bartholomew, J.L.; El-Matbouli, M. Transcriptome Analysis Elucidates the Key Responses of Bryozoan Fredericella sultana during the Development of Tetracapsuloides bryosalmonae (Myxozoa). Int. J. Mol. Sci. 2020, $21,5910$. [CrossRef]

52. Niu, D.; Xie, S.; Bai, Z.; Wang, L.; Jin, K.; Li, J. Identification, expression, and responses to bacterial challenge of the cathepsin C gene from the razor clam Sinonovacula constricta. Dev. Comp. Immunol. 2014, 46, 241-245. [CrossRef] [PubMed] 
53. Moreira, R.; Balseiro, P.; Romero, A.; Dios, S.; Posada, D.; Novoa, B.; Figueras, A. Gene expression analysis of clams Ruditapes philippinarum and Ruditapes decussatus following bacterial infection yields molecular insights into pathogen resistance and immunity. Dev. Comp. Immunol. 2012, 36, 140-149. [CrossRef] [PubMed]

54. Xie, S.; Niu, D.; Du, Y.; Wei, K.; Nguyen, H.D.; Li, J. Expression and characterization of insulin-like growth factor II mRNA binding protein in the razor clam Sinonovacula constricta. Aquacult. Fish. 2017, 2, 247-255. [CrossRef]

55. Araya, M.T.; Siah, A.; Mateo, D.; Markham, F.; McKenna, P.; Johnson, G.; Berthe, F.C.J. Selection and evaluation of housekeeping genes for haemocytes of soft-shell clams (Mya arenaria) challenged with Vibrio splendidus. J. Invtebrar. Pathol. 2008, 99, 326-331. [CrossRef]

56. Mateo, D.R.; Greenwood, S.J.; Araya, M.T.; Berthe, F.C.J.; Johnson, G.R.; Siah, A. Differential gene expression of y-actin, Toll-like receptor 2 (TLR-2) and interleukin-1 receptor-associated kinase 4 (IRAK-4) in Mya arenaria haemocytes induced by In Vivo infections with two Vibrio splendidus strains. Dev. Comp. Immunol. 2010, 34, 710-714. [CrossRef]

57. Chen, I.H.; Chou, L.S.; Chou, S.J.; Wang, J.H.; Stott, J.; Blanchard, M.; Jen, I.F.; Yang, W.C. Selection of suitable reference genes for normalization of quantitative RT-PCR in peripheral blood samples of bottlenose dolphins (Tursiops truncatus). Sci. Rep. 2015, 5, 15425. [CrossRef]

58. Brulle, F.; Morgan, A.J.; Coquerelle, C.; Vandenbulcke, F. Transcriptomic underpinning of toxicant-mediated physiological function alterations in three terrestrial invertebrate taxa: A review. Environ. Pollut. 2010, 158, 2793-2808. [CrossRef] [PubMed]

59. Coletti, H.A.; Bodkin, J.L.; Monson, D.H.; Ballachey, B.E.; Dean, T.A. Detecting and Inferring Cause of Change in an Alaska Nearshore Marine Ecosystem. Ecosphere 2016, 7, e01489. [CrossRef]

60. Kennish, M.J.; Brush, M.J.; Moore, K.A. Drivers of change in shallow coastal photic systems: An introduction to a special issue. Estuar. Coast. 2014, 37, S3-S19. [CrossRef]

61. Ford, S.E.; Smolowitz, R. Infection dynamics of an oyster parasite in its newly expanded range. Mar. Biol. 2007, 151, 119-133. [CrossRef]

62. Meyers, T.; Burton, T. Diseases of Wild and Cultured Shellfish in Alaska; Fish Pathology Laboratories, Alaska Department of Fish and Game: Anchorage, AK, USA, 2009.

63. McKellar, J.M. Growth and Maturity of the Pacific Razor Clam in Eastern Cook Inlet, Alaska. Master's Thesis, University of Alaska, Fairbanks, AK, USA, 2014. Available online: http:/ /hdl.handle.net/11122/4811 (accessed on 22 October 2020).

64. Elston, R.A. An intranuclear pathogen [nuclear inclusion X (NIX)] associated with massive mortalities of the Pacific razor clam, Siliqua patula. J. Inver. Path. 1986, 47, 93-104. [CrossRef]

65. Travis, B.A.; Batts, W.N.; Groner, M.L.; Hershberger, P.K.; Fradkin, S.C.; Conway, C.M.; Park, L.; Purcell, M.K. Novel diagnostic tests for the putative agent of bacterial gill disease in Pacific razor clams (Siliqua patula). J. Invertebr. Pathol. 2021, 178, 107519. [CrossRef] [PubMed]

66. Johnston, E.L.; Mayer-Pinto, M.; Crowe, T.P. Review: Chemical contaminant effects on marine ecosystem functioning. J. Appl. Ecol. 2015, 52, 140-149. [CrossRef]

67. Rider, M.; Apeti, D.A.; Jacob, A.; Kimbrough, K.; Davenport, E.; Bower, M.; Coletti, H.; Esler, D. A Synthesis of Ten Years of Chemical Contaminants Monitoring in National Park Service—Southeast and Southwest Alaska Networks; NOAA Technical Memorandum NOS NCCOS 277; NOAA: Washington, DC, USA, 2020; p. 110. [CrossRef]

68. Larrance, J.D.; Chester, A.J. Source, Composition, and Flux of Organic Detritus in Lower Cook Inlet; OCSEAP Final Report; U.S. Department of Commerce, NOAA: Washington, DC, USA, 1979; pp. 1-71.

69. Coyle, K.O.; Hermann, A.J.; Hopcroft, R.R. Modeled spatial-temporal distribution of productivity, chlorophyll, iron and nitrate on the northern Gulf of Alaska shelf relative to field observations. Deep-Sea Res. Pt. II 2019, 165, 163-191. [CrossRef]

70. Swan, E.F. The growth of the clam Mya arenaria as affected by the substratum. Ecology 1952, 33, 530. [CrossRef]

71. Richardson, C.A. Molluscs as archives of environmental change. Oceanogr. Mar. Biol. 2001, 39, $103-164$.

72. Newell, C.R.; Hidu, H. The effects of sediment type on growth rate and shell allometry in the Soft-shelled Clam, Mya arenaria. J. Exp. Mar. Biol. Ecol. 1982, 65, 285-295. [CrossRef]

73. Lomovasky, B.J.; Lasta, M.; Valiñas, M.; Bruschetti, M.; Ribeiro, P.; Campodónico, S.; Iribarne, O. Differences in shell morphology and internal growth pattern of the Patagonian scallop Zygochlamys patagonica in the four main beds across their SW Atlantic distribution range. Fish. Res. 2008, 89, 266-275. [CrossRef]

74. Hernández-Otero, A.; Gaspar, M.B.; Macho, G.; Vázquez, E. Age and growth of the sword razor clam Ensis arcuatus in the Ria de Pontevedra (NW Spain): Influence of environmental parameters. J. Sea Res. 2014, 85, 59-72. [CrossRef]

75. Addino, M.S.; Alvarez, M.F.; Brey, T.; Iribarne, O.; Lomovasky, B.J. Growth changes of the stout razor clam Tagelus plebeius (Lightfoot, 1786) under different salinities in SW Atlantic estuaries. J. Sea. Res. 2019, 146, 14-23. [CrossRef]

76. Walsh, J.E.; Thoman, R.L.; Bhatt, U.S.; Bieniek, P.A.; Brettschneider, B.; Brubaker, M.; Danielson, S.; Lader, R.; Fetterer, F.; Holderied, K.; et al. The high latitude marine heat wave of 2016 and its impacts on Alaska. Bull. Am. Meteorol. Soc. 2018, 99, S39-S43. [CrossRef]

77. Holbrook, N.J.; Scannell, H.A.; Gupta, A.S.; Benthuysen, J.A.; Feng, M.; Oliver, E.C.; Alexander, L.V.; Burrows, M.T.; Donat, M.G.; Hobday, A.J.; et al. A global assessment of marine heatwaves and their drivers. Nat. Commun. 2019, 10, 2624. [CrossRef] [PubMed] 
78. Weitzman, B.; Konar, B.; Iken, K.; Coletti, H.; Monson, D.; Suryan, R.; Dean, T.; Hondolero, D.; Lindeberg, M. Changes in Rocky Intertidal Community Structure During a Marine Heatwave in the Northern Gulf of Alaska. Front. Mar. Sci. 2021, 8, 556820. [CrossRef]

79. Counihan, K.; Bowen, L.; Ballachey, B.; Coletti, H.; Hollmen, T.; Pister, B.; Wilson, T.L. Physiological and gene transcription assays in combination: A new paradigm for marine intertidal assessment. PeerJ 2019, 7, e7800. [CrossRef]

80. Bowen, L.; Miles, A.K.; Ballachey, B.; Waters, S.; Bodkin, J. Gene Transcript Profiling in Sea Otters Post-Exxon Valdez Oil Spill: A Tool for Marine Ecosystem Health Assessment. J. Mar. Sci. Eng. 2016, 4, 39. [CrossRef]

81. Tinker, T.M.; Bodkin, J.L.; Bowen, L.; Ballachey, B.; Bentall, G.; Burdin, A.; Coletti, H.; Esslinger, G.; Hatfield, B.B.; Kenner, M.C.; et al. Sea otter population collapse in southwest Alaska: Assessing ecological covariates, consequences, and causal factors. Ecol. Monogr. 2021, 91, e01472. [CrossRef]

82. Konar, B.; Mitchell, T.J.; Iken, K.; Coletti, H.; Dean, T.; Esler, D.; Lindberg, M.; Pister, B.; Weitzman, B. Wasting disease and environmental variables drive sea star assemblages in the northern Gulf of Alaska. J. Exp. Mar. Biol. Ecol. 2019, 520, 151209. [CrossRef]

83. Weitzman, B.P. Sea Urchin Ecology: Effects of Food-Web Modification, Climate Change and Community Structure. Ph.D. Thesis, University of Alaska, Fairbanks, AK, USA, 2020.

84. Erlenbach, J.A. Nutritional and Landscape Ecology of Brown Bears (Ursus arctos). Ph.D. Thesis, Washington State University, Pullman, WA, USA, 2020.

85. Estes, J.A.; Palmisano, J.F. Sea otters: Their role in structuring nearshore communities. Science 1974, 185, 1058-1060. [CrossRef] [PubMed]

86. Garshelis, D.L.; Garshelis, J.A.; Kimker, A.T. Sea Otter Time Budgets and Prey Relationships in Alaska. J. Wildl. Manag. 1986, 50, 637-647. Available online: https://www.jstor.org/stable/3800974 (accessed on 16 August 2020). [CrossRef]

87. Riedman, M.; Estes, J.A. The Sea Otter (Enhydra Lutris): Behavior, Ecology, and Natural History; U.S. Fish and Wildlife Service, Biological Report; U.S. Fish and Wildlife Service: Washington, DC, USA, 1990; Volume 90, pp. 1-126.

88. Kvitek, R.G.; Oliver, J.S.; DeGange, A.R.; Anderson, B.S. Changes in Alaskan soft-bottom prey communities along a gradient in sea otter predation. Ecology 1992, 73, 413-428. [CrossRef]

89. Estes, J.A.; Duggins, D.O. Sea Otters and Kelp Forests in Alaska: Generality and Variation in a Community Ecological Paradigm. Ecol. Monogr. 1995, 65, 75-100. [CrossRef]

90. Hughes, B.B.; Eby, R.; Van Dyke, E.; Tinker, M.T.; Marks, C.I.; Johnson, K.S.; Wasson, K. Recovery of a top predator mediates negative eutrophic effects on seagrass. Proc. Natl. Acad. Sci. USA 2013, 110, 15313-15318. [CrossRef]

91. Kenyon, K.W. The Sea Otter in the Eastern Pacific Ocean. North Am. Fauna 1969, 68, 1-352. [CrossRef]

92. Bodkin, J.L. Historic and contemporary status of sea otters in the North Pacific. In Sea Otter Conservation; Larson, S.E., Bodkin, J.L., VanBlaricom, G.R., Eds.; Elsevier: Amsterdam, The Netherlands, 2015; pp. 46-61.

93. Wendell, F. Relationship between sea otter range expansion and red abalone abundance and size distribution in central California. Calif. Fish Game 1994, 80, 45-56.

94. Wendell, F.E.; Hardy, R.A.; Ames, J.A.; Burge, R.T. Temporal and spatial patterns in sea otter (Enhydra lutris) range expansion and in the loss of the Pismo clam fisheries. Calif. Fish. Game 1986, 72, 197-212.

95. Watson, J.C.; Smith, T.G. The effect of sea otters on shellfisheries in British Columbia. In Invertebrate Working Papers; Hand, C.M., Waddell, B.J., Eds.; Reviewed by the Pacific Assessment Review Committee (PSARC) in 1993 and 1994; No. 2089; Canadian Technical Report of Fisheries and Aquatic Sciences: Ottawa, ON, Canada, 1996; pp. 262-303.

96. Estes, J.A.; VanBlaricom, G.R. Sea-otters and shellfisheries. In Marine Mammals and Fisheries; Beddington, R., Beverton, R.J.H., Lavigne, D.M., Eds.; George Allen \& Unwin: Crows Nest, Australia, 1985; pp. 187-235.

97. Larson, S.D.; Hoyt, Z.N.; Eckert, G.L.; Gill, V.A. Impacts of sea otter (Enhydra lutris) predation on commercially important sea cucumbers (Parastichopus californicus) in southeast Alaska. Can. J. Fish. Aquat. Sci. 2013, 70, 1498-1507. [CrossRef]

98. Hoyt, Z.N. Resource Competition, Space Use and Forage Ecology of Sea Otters, Enhydra lutris, in Southern Southeast Alaska. Ph.D. Thesis, University of Alaska, Fairbanks, AK, USA, 2015.

99. Doroff, A.M.; DeGange, A.R. Sea otter, Enhydra lutris, prey composition and foraging success in the northern Kodiak Archipelago. Fish. Bull. 1994, 92, 704-710.

100. Dean, T.A.; Bodkin, J.L.; Fukuyama, A.K.; Jewett, S.C.; Monson, D.H.; O'Clair, C.E.; VanBlaricom, G.R. Food limitation and the recovery of sea otters in Prince William Sound. Mar. Ecol. Prog. Ser. 2002, 241, 255-270. [CrossRef]

101. Bodkin, J.L.; Monson, D.H.; Esslinger, G.G. Results of the 2002 Kenai Peninsula and Lower Cook Inlet Aerial Sea Otter Survey; Alaska Science Center Report; U.S. Geological Survey: Reston, VA, USA, 2003.

102. Mangipane, B. Sea Otter Aerial Distribution Surveys along the Lake Clark Coast; NPS: Anchorage, AK, USA, 2018; Unpublished materials intended for publication. 